Volume 16 (1) (2020) : 1-22
Jurnal Borneo Administrator
$\mathrm{p}$-issn : 1858-0300; e-issn : 2407-6767
$\mathrm{http://samarinda.lan.go.id/jba}$
$\mathrm{DOl}: 10.24258 / j \mathrm{jba.v16i1.588}$

\title{
KETERLIBATAN SIKLUS TERINTEGRASI KNOWLEDGE MANAGEMENT TERHADAP PERILAKU KERJA INOVATIF SUMBER DAYA MANUSIA DI BALAI DIKLAT KEUANGAN YOGYAKARTA
}

\section{THE INVOLVEMENT OF INTEGRATED KNOWLEDGE MANAGEMENT CYCLE TOWARDS HUMAN RESOURCE INNOVATIVE WORK BEHAVIOR IN FINANCIAL EDUCATION AND TRAINING AGENCY YOGYAKARTA}

\author{
Bagas Dwi Praptowo a, Mikhriani a , dan Agus Suharsono b \\ a Manajemen Dakwah Fakultas Dakwah dan Komunikasi UIN Sunan Kalijaga \\ Yogyakarta \\ Jl. Marsda Adisucipto Yogyakarta 55281 \\ b Balai Diklat Keuangan Yogyakarta \\ Jl. Solo KM. 11 Sleman Yogyakarta 55571, \\ Email: bedepeee@gmail.com; mikhriani1994@gmail.com; \\ gusharpramudito@gmail.com
}

Naskah diterima: 30 Oktober 2019; revisi terakhir: 27 Desember 2019; disetujui 8 Januari 2020

How to Cite: Praptowo, Bagas D., Mikhriani, dan Suharsono, Agus. (2020). Keterlibatan Siklus Terintegrasi Knowledge Management Terhadap Perilaku Kerja Inovatif Sumber Daya Manusia di Balai Diklat Keuangan Yogyakarta. Jurnal Borneo Administrator, 16 (1), 1-22. https://doi.org/10.24258/jba.v16i1.588

\section{Abstract}

To realize Knowledge Management as one of pillars of Ministry of Finance Corporate University, Financial Education and Training Agency Yogyakarta as an institution that carries out a role of building a learning environment needs to have a series of systems and procedures for managing financial knowledge so that is available and well managed. This study aims to prove efforts effective influencing Human Resource (HR) Innovative Work Behavior in Financial Education and Training Agency Yogyakarta are through an integrated Knowledge Management Cycle namely Knowledge Capture, Knowledge Sharing and Dissemination, Knowledge Acquisition and Application. This integrated cycle can stimulate $H R$ in critical, creative, and innovative thinking to produce useful new knowledge. This research method was a quantitative approach to SEM analysis using Smart PLS software. The results of the study proved that Knowledge Acquisition and Application affect the HR Innovative Work Behavior. However, Knowledge Capture and Knowledge Sharing and Dissemination did not affect HR Innovative Work Behavior, this indicates that there was a need to increase Knowledge Capture and Knowledge Sharing and Dissemination at Financial Education and Training Agency Yogyakarta so that overall employees could contribute 
to fostering Innovative Work Behavior in accordance under BPPK Decree No. KEP140/PP/2017 which regulates that Knowledge Management is all employees' task of Ministry of Finance.

Keywords: Knowledge Capture, Knowledge Sharing and Dissemination, Knowledge Acquisition and Application, Human Resource (HR) Innovative Work Behavior

\begin{abstract}
Abstrak
Mewujudkan Knowledge Management sebagai salah satu pilar Kemenkeu Corporate University, Balai Diklat Keuangan Yogyakarta sebagai instansi yang menjalankan peran membangun lingkungan pembelajaran, perlu memperhatikan rangkaian sistem dan prosedur dalam mengelola pengetahuan keuangan negara agar tersedia dan terkelola dengan baik. Penelitian ini bertujuan untuk membuktikan bahwa upaya yang dipandang efektif dalam mempengaruhi Perilaku Kerja Inovatif SDM di Balai Diklat Keuangan Yogyakarta adalah melalui siklus terintegrasi dari tiga tahapan Knowledge Management, yaitu Knowledge Capture, Knowledge Sharing and Dissemination, Knowledge Acquisition and Application. Siklus terintegrasi tersebut dapat merangsang SDM untuk berfikir kritis, kreatif, dan inovatif sehingga menghasilkan pengetahuan baru yang berguna. Metode penelitian ini melalui pendekatan kuantitatif analisis SEM menggunakan software Smart PLS. Hasil penelitian membuktikan bahwa Knowledge Acquisition and Application berpengaruh terhadap Perilaku Kerja Inovatif SDM. Namun, Knowledge Capture dan Knowledge Sharing and Dissemination tidak berpengaruh terhadap Perilaku Kerja Inovatif SDM. Hal ini mengindikasikan bahwa perlunya peningkatan Knowledge Capture dan Knowledge Sharing and Dissemination di Balai Diklat Keuangan Yogyakarta agar secara keseluruhan pegawai dapat berkontribusi menumbuhkan Perilaku Kerja Inovatif sesuai Keputusan Kepala BPPK No. KEP-140/PP/2017 yang mengatur bahwa tugas Knowledge Management adalah seluruh pegawai Kemenkeu.
\end{abstract}

Kata kunci: Knowledge Capture, Knowledge Sharing and Dissemination, Knowledge Acquisition and Application, Perilaku Kerja Inovatif SDM

\title{
A. PENDAHULUAN
}

Arah pengembangan Aparatur Sipil Negara (ASN) pada Grand Design RPJM ke-4 periode tahun 2020-2024 adalah Word Class Government dengan 4 kebijakan pengembangan kompetensi ASN yaitu melalui pembaharuan kurikulum, menerapkan sistem pelatihan berbasis blended learning, pengelola ASN Corporate University, dan penguatan kapasitas tenaga pelatih atau widyaiswara (BAPPENAS, 2019:101-111) (Pemerintah RI, 2010:13-19). ASN Corporate University merupakan salah satu arah kebijakan pengembangan kompetensi ASN, baik pada tingkat kementerian, lembaga negara, maupun pemerintah daerah (Hatmoko \& Suharsono, 2018:82). Pentingnya Badan Pengembangan Sumber Daya Manusia pada pemerintahan, yaitu untuk dapat berperan dalam mewujudkan Corporate University sehingga dapat mengubah potensi ASN yang ada menjadi investasi sumber daya manusia (SDM) yang bercirikan birokrasi kelas dunia yaitu memiliki nilai tambah, inovatif, handal, dan berkualitas (Sartika, 2018:2). Dengan semangat Corporate University lembaga diklat akan lebih responsif terhadap pembelajaran organisasi dan paradigma pemerintah akan bergeser menjadi lebih tegas dalam meningkatkan kompetensi ASN. Mengembangkan kemampuan pembelajar dengan kurikulum yang tepat dengan 
kombinasi pemanfaatan teknologi yang canggih, akan menuntun ASN untuk dapat lebih memacu kompetensinya dimanapun dan kapanpun (PKP2A III LAN, 2018:22).

Badan Pendidikan dan Pelatihan Keuangan (BPPK), Kementerian Keuangan memiliki peran strategis dalam mengelola pengembangan ASN yang kompeten, akuntabel, dan andal melalui proses pembelajaran menggunakan strategi Kemenkeu Corporate University (LaKin BPPK, 2017:57). Dengan kebijakan yang tepat dan pengelolaan yang baik dalam menerapkan strategi Kemenkeu Corporate University, kualitas ASN dapat terus meningkat sehingga dapat memberikan kontribusi terbaiknya bagi pemerintah (Edukasi Keuangan BPPK, 2018:7). Proses pembelajaran Corporate University dalam Keputusan Kepala BPPK No. KEP-140/PP/2017 tentang Cetak Biru Kemenkeu Corpu lazimnya menerapkan model 70-20-10 dengan utilisasi Knowledge Management guna menumbuhkan budaya belajar atau learning with passion (KaBPPK, 2017). Oleh karena itu, pilar dari pembelajaran yang dilaksanakan oleh Kemenkeu Corporate University adalah Knowledge Management (Edukasi Keuangan BPPK, 2017:6). Hal tersebut merupakan pendukung utama kegiatan pembelajaran dengan pondasi utamanya adalah Learning Strategy Governance melalui tata kelola strategi pembelajaran yang baik diharapkan dapat mendukung keseluruhan kegiatan pembelajaran yang dilaksanakan (LaKin BPPK, 2017:57).

Kesadaran dalam menerapkan Knowledge Management mampu mendorong organisasi pembelajar untuk lebih berinovatif (Sangkala, 2007:5). Inovasi dalam organisasi penting karena dapat meningkatkan efektivitas proses internal dan kualitas hasil, untuk mencapai dan mempertahankan keunggulan kompetitif, dan untuk mengamankan kelangsungan hidup jangka panjang organisasi. Karena inovasi, organisasi dapat menumbuhkan struktur kerja yang lebih fleksibel. Inovasi dalam organisasi membutuhkan SDM untuk berkontribusi terhadap perubahan dan peningkatan kinerja (Mesmann, 2012:4). Gailly dalam Etikariena (2018:108) menyatakan bahwa tantangan yang kemudian muncul adalah bagaimana membawa SDM yang ada di organisasi agar dapat menerapkan inovasi dalam konteks tugasnya, dalam hal ini tugas sebagai urgensi Knowledge Management.

Knowledge Management merupakan sebuah sistem untuk mengelola pengetahuan dalam bentuk sarana digital melalui platform berbasis web (McInerney \& Koenig, 2011:1). Oleh karena itu, implementasi praktik Knowledge Management pada unit diklat BPPK memanfaatkan e-learning dengan menciptakan, menyimpan dan membagi pengetahuan melalui video pembelajaran pada website Kemenkeu Learning Center. Di bawah ini adalah tabel jumlah video pembelajaran yang di-upload oleh unit diklat daerah BPPK dalam website Kemenkeu Learning Center.

Tabel 1.

Jumlah Video Pembelajaran Yang Di-upload oleh Unit Diklat Daerah BPPK

\begin{tabular}{clc}
\hline No & Unit Diklat Daerah BPPK & Jumlah Video Dalam KLC \\
\hline 1 & BDK Medan & 27 \\
2 & BDK Pekanbaru & 17 \\
3 & BDK Palembang & 29 \\
4 & BDK Cimahi & 61 \\
5 & BDK Yogyakarta & 78 \\
6 & BDK Malang & 56 \\
7 & BDK Denpasar & 18 \\
8 & BDK Pontianak & 62 \\
9 & BDK Balikpapan & 26 \\
10 & BDK Makassar & 25
\end{tabular}




\begin{tabular}{lll}
11 & BDK Manado & 19 \\
12 & BD PIM Magelang & 52 \\
\hline
\end{tabular}

Sumber : https://klc.kemenkeu.go.id/Sampai dengan 30-10-2019

Setidaknya Balai Diklat Keuangan Yogyakarta lebih aktif dari unit diklat lain dalam produksi video pembelajaran, walaupun sampai saat ini masih didominasi oleh widyaiswara (Subangun, 2018:753; Suharsono, 2018:13). Keputusan Kepala BPPK Nomor KEP140/PP/2017 mengatur bahwa pembelajaran Kemenkeu Corporate University seharusnya bukan hanya menjadi tanggung jawab unit penyelenggara diklat, tetapi menjadi tanggung jawab seluruh unit eselon I di lingkungan Kementerian Keuangan. Agar pembelajaran link and match dengan kebutuhan, diperlukan sinergi yang kuat antar seluruh elemen ASN yang ada (KaBPPK, 2017) tidak hanya widyaiswara saja tetapi ASN yang memiliki keahlian teknis atau Skill Group Owner (SGO) di Balai Diklat Keuangan Yogyakarta dapat berperan penting mewujudkan Perilaku Kerja Inovatif dalam Knowledge Management karena SGO memiliki tugas untuk: (1) bekerja sama dengan knowledge \& learning analyst (widyaiswara) dalam melaksanakan pemetaan kompetensi yang dibutuhkan untuk peningkatan kinerja organisasi; (2) melakukan inventarisasi kompetensi dan merumuskan program pembelajaran; (3) diseminasi best practices dalam organisasi; (4) memberikan, membagi tacit knowledge, explicit knowledge, expertise, know how, experience terkait kompetensi teknis untuk bahan Knowledge Management (Suharsono, 2018:13). Oleh karena itu, diperlukan adanya optimalisasi dan efektivitas praktik Knowledge Management serta implikasinya pada inovasi (Darroch, 2005:112) karena perilaku kerja inovatif tidak akan terjadi jika tidak didukung dengan sebuah koordinasi yang disengaja dan sistematis dari SDM, proses, dan teknologi untuk menambah nilai melalui penggunaan kembali ilmu pengetahuan dan inovasi. Koordinasi tersebut didasarkan pada siklus terintegrasi dari tiga tahapan, yaitu Knowledge Capture (Penciptaan Pengetahuan), Knowledge Sharing and Dissemination (Berbagi dan Transfer Pengetahuan) dan Knowledge Acquisition and Application (Akuisisi dan Aplikasi Pengetahuan) (Dalkir, 2013:43). Pentingnya perilaku kerja inovatif SDM dalam organisasi pembelajar memberi indikasi bahwa untuk mencapai siklus terintegrasi tersebut, ASN di Balai Diklat Keuangan Yogyakarta menjadi motor penggerak utama sehingga dapat mewujudkan organisasi pembelajar dalam mencapai manajemen pengetahuan secara kontinyu.

Urgensi dan peran Kemenkeu Corporate University bukan sekadar strategi pengembangan SDM. Lebih dari itu, sebagai organisasi pembelajar, aktivitas manajemen pengetahuan dalam lingkungan kerja menjadi pusat dari semua bagian manajerial, perilaku kerja dan penyediaan sistem. Oleh karena itu perlu dikaji penerapan utilitasi Knowledge Management sebagai salah satu pilar Kemenkeu Corporate University dari seluruh individu, tim, dan organisasi dalam lingkungan Kementerian Keuangan. Pada akhirnya akan dibuktikan bahwa apakah upaya yang dipandang efektif dalam mempengaruhi Perilaku Kerja Inovatif SDM di Balai Diklat Keuangan Yogyakarta melalui siklus terintegrasi dari tiga tahapan Knowledge Management yaitu Knowledge Capture, Knowledge Sharing and Dissemination, Knowledge Acquisition and Application. Siklus terintegrasi tersebut dapat merangsang SDM dalam berfikir kritis, kreatif, dan inovatif sehingga menghasilkan pengetahuan baru yang berguna bagi seluruh ASN Kementerian Keuangan. Perlunya kesadaran seluruh elemen penggerak Kemenkeu Corporate University dalam mewujudkan perilaku kerja inovatif SDM menyiratkan bahwa siklus terintegrasi dari tiga tahapan Knowledge Management tidak hanya berada pada tahap berbagi dan menggunakan kembali 
pengetahuan, tetapi mengubah potensi ASN Kementerian Keuangan menjadi investasi SDM yang memiliki value, inovatif, andal, dan berkualitas.

\section{B. METODE PENELITIAN}

Jenis penelitian ini adalah explanatory research, yaitu penelitian dengan maksud dan tujuan untuk menjelaskan hubungan kausal antara variabel-variabel penelitian dan menguji hipotesis yang telah dirumuskan. Penelitian dilakukan di Balai Diklat Keuangan Yogyakarta. Karena jumlah populasi pada penelitian ini terhitung sedikit, peneliti melakukan penarikan sampel dengan menggunakan teknik sensus, yaitu seluruh pegawai Aparatur Sipil Negara (ASN) Balai Diklat Keuangan Yogyakarta dengan berjumlah 33 pegawai. Bentuk variabel mayor dalam penelitian ini adalah Knowledge Management $(\mathrm{X})$ dengan variabel minor yaitu Knowledge Capture (X1), Knowledge Sharing and Dissemination (X2), dan Knowledge Acquisition and Application (X3) karena menjadi penyebab atas timbulnya variabel terikat, yaitu Perilaku Kerja Inovatif SDM (Y).

Untuk memperoleh data dalam penelitian ini digunakan beberapa teknik, yaitu metode penyebaran kuesioner (diawali dengan tryout), dokumentasi, dan pengamatan langsung. Perolehan data melalui penyebaran kuesioner disusun dan diadaptasi dari dua sumber, yang pertama untuk variabel Knowledge Management melalui penelitian Trevor Vernon Downes yang berjudul An Evaluation of Knowledge Management Practices in Nonprofit Community Services Organisations in Australia (Downes, 2014:48-52). Yang kedua untuk variabel Perilaku Kerja Inovatif SDM melalui penelitian Onne Jansen yang berjudul Job demands, Perceptions of Effort-reward Fairness and Innovative Work Behavior (Janssen, 2000). Data dokumentasi dan pengamatan didapat langsung dari berbagai sumber terkait variabel penelitian.

\section{Prosedur dan Analisis Data}

Prosedur analisis data diawali dengan tryout uji validitas dan reliabilitas kuesioner kepada 30 responden, selanjutnya peneliti melakukan penyebaran langsung kuesioner kepada seluruh responden di Balai Diklat Keuangan Yogyakarta. Pengujian validitas dan reliabilitas kuesioner saat tryout dan setelahnya dilakukan dengan software IBM SPSS Statistics, selain itu dilakukan juga analisis data deskriptif responden dan analisis statistik deskriptif. Dalam rangka pengujian hipotesis, peneliti menggunakan teknik statistik Structural Equation Modelling (SEM) dengan software Smart PLS (Partial Least Square). Pada PLS Path Modeling terdapat 2 model pengujian, yaitu Outer Model (Model Pengukuran) dan Inner Model (Model Struktural).

Pengujian Outer Model mendefinisikan bagaimana setiap indikator berhubungan dengan variabel latennya. Tahapan uji yang dilakukan pada outer model adalah (1) Convergent Validity, yaitu nilai loading factor pada variabel laten dengan indikatornya diharapkan > 0.7. (2) Discriminant Validity, untuk mengetahui apakah item memiliki diskriminan yang memadai, dengan membandingkan nilai cross loading pada item variabel diharapkan lebih besar dari nilai cross loading item variabel yang lain. (3) Average Varance Extracted (AVE), nilai AVE yang baik disyaratkan > 0.5. (4) Composite Reliability, jika nilai composite reliability $>0.7$, maka tingkat reliabilitas tinggi.

Pengujian Inner Model dilakukan untuk menguji hubungan antara konstruksi laten. Inner Model memiliki beberapa uji yang harus dilakukan, yaitu (1) Nilai $R$ Square, digunakan untuk mengukur seberapa besar pengaruh keseluruhan variabel laten independen terhadap variabel laten dependen, dengan kata lain menguji pengaruh hipotesis mayor, dengan ketentuan jika nilai sebesar 0.67 (kuat), 0.33 (moderat) dan 0.19 (lemah). (2) 
Estimate for Path Coefficient, nilai koefisien jalur untuk menentukan besarnya hubungan variabel secara terpisah atau pengujian hipotesis minor dengan metode bootstrapping.

\section{Perumusan Hipotesis}

Praktik Knowledge Management, seperti pengumpulan pengetahuan, mengelola, berbagi, belajar, dan menggunakan kembali pengetahuan mengambil peran penting dalam membawa perilaku organisasi menjadi lebih berinovatif. Selain itu, individu yang dengan cepat menangkap dan menerapkan pengetahuan baru di seluruh organisasi dapat mendorong sebuah perilaku kerja inovatif (Rahimi, Rostami, Shad, \& Vafaei, 2017:71-72). Dengan adanya praktik Knowledge Management tersebut, individu dalam organisasi akan berusaha mencari dan mengolah pengetahuan yang mereka miliki yang nantinya akan direpresentasikan menjadi sebuah perilaku kerja yang inovatif dan diaplikasikan dalam organisasi sehingga dapat meningkatkan efektivitas dan produktivitas kerja (Ikrahmawati, 2016). Dengan penjelasan tersebut, dapat dirumuskan hipotesis mayor dalam penelitian ini yaitu: Hipotesis Mayor: Knowledge Management $(\mathrm{X})$ berpengaruh terhadap Perilaku Kerja Inovatif SDM (Y)

Knowledge Capture (penangkapan atau menciptakan pengetahuan) telah menekankan peran individu sebagai SDM yang bekerja untuk organisasi karena hampir semua individu melakukan kegiatan penciptaan atau penangkapan pengetahuan dalam melaksanakan pekerjaan mereka (Dalkir, 2013:81). Dimensi penangkapan pengetahuan yang meliputi sosialisasi, eksternalisasi, kombinasi, dan internalisasi merupakan sebuah proses yang melibatkan interaksi dalam berbagi ide, gagasan, dan tukar pikiran oleh individu pada kelompok bahkan organisasi (Nonaka et al., 2018:5-7). Sebuah ide, gagasan, tukar pikiran tidak akan terjadi tanpa adanya inisiatif dari individu itu sendiri. Maka dari itu pentingnya perilaku kerja inovatif SDM dalam organisasi agar individu dapat mewujudkan ide-ide inovatif yang berguna bagi seluruh individu lainnya dalam pencapaian tujuan organisasi (Ikrahmawati, 2016). Maka dari itu dapat dirumuskan hipotesis minor 1 sebagai berikut: Hipotesis Minor 1: Knowledge Capture (X) berpengaruh terhadap Perilaku Kerja Inovatif SDM (Y)

Knowledge Sharing and Dissemination (berbagi dan diseminasi pengetahuan) dianggap sebagai alat untuk menumbuhkan perilaku inovatif dalam diri individu, memfasilitasi kegiatan inovatif, dan merangsang pemikiran kritis, yang menghasilkan peningkatan kemampuan dalam menerjemahkan gagasan ke dalam inovasi yang menunjukkan bahwa ketika pengetahuan dibagikan di antara individu, mereka lebih cenderung untuk menguraikan, mengintegrasikan, dan menerjemahkan informasi daripada hanya meneruskannya ke penerima. Hal ini menunjukkan keterlibatan dalam perilaku kerja inovatif yang mencakup mencari peluang untuk perubahan dan penerapannya pada praktik kerja yang ada (Abukhait, Bani-Melhem, \& Zeffane, 2018:5-6). Maka dari itu pengetahuan harus mengalir secara bebas di dalam organisasi karena semakin baik penyebaran pengetahuan, semakin besar kemungkinan inovasi SDM yang dihasilkan (Darroch, 2005:105). Oleh karena itu, dapat dirumuskan hipotesis minor 2 yaitu sebagai berikut.

Hipotesis Minor 2: Knowledge Sharing and Dissemination $\left(\mathrm{X}_{2}\right)$ berpengaruh terhadap Perilaku Kerja Inovatif SDM (Y)

Knowledge Acquisition and Application (akuisisi dan aplikasi pengetahuan) menjadi sebuah proses pengambilalihan pengetahuan oleh organisasi kemudian menggabungkan pengetahuan yang telah tersedia untuk kepentingan organisasi, pada akhirnya pengetahuan dapat digunakan kembali (Liao \& Wu, 2009:1850-1854). Tidak jauh beda seperti yang dinyatakan oleh Dalkir bahwa setelah pengetahuan diakuisisi kemudian disimpan melalui 
sebuah wadah yang telah disediakan organisasi seperti perpustakaan atau media penyimpanan berbasis web, maka pengetahuan dapat digunakan atau diaplikasikan kembali oleh seluruh individu (Dalkir, 2013:146). Namun, efek terpenting dari mengakuisisi dan mengaplikasikan kembali pengetahuan harus terkait dengan kreativitas dan inovasi organisasi, karena berbagi pengetahuan yang sudah menjadi aktivitas orgasasi, tidak hanya berarti kembali pada transfer pengetahuan, keterampilan, dan informasi yang efektif, tetapi individu juga perlu menunjukkan bagaimana melakukan penciptaan pengetahuan yang baru dan memunculkan kembali ide-ide inovatif dari pengetahuan yang telah disediakan (Lee, 2018:3). Berdasarkan penjelasan tersebut dapat dirumuskan hipotesis minor 3, yaitu:

Hipotesis Minor 3: Knowledge Acquisition and Application $\left(\mathrm{X}_{3}\right)$ berpengaruh terhadap Perilaku Kerja Inovatif SDM (Y)

Hipotesis mayor pada penelitian ini adalah Knowledge Management (X) yang memiliki hubungan dan berpengaruh terhadap Perilaku Kerja Inovatif SDM di Balai Diklat Keuangan Yogyakarta (Y). Hipotesis minor pada penelitian ini yaitu Knowledge Capture $\left(\mathrm{X}_{1}\right)$ Knowledge Sharing and Dissemination $\left(\mathrm{X}_{2}\right)$ dan Knowledge Acquisition and Application $\left(\mathrm{X}_{3}\right)$ yang memiliki hubungan dan berpengaruh positif dan signifikan terhadap Perilaku Kerja Inovatif SDM di Balai Diklat Keuangan Yogyakarta.

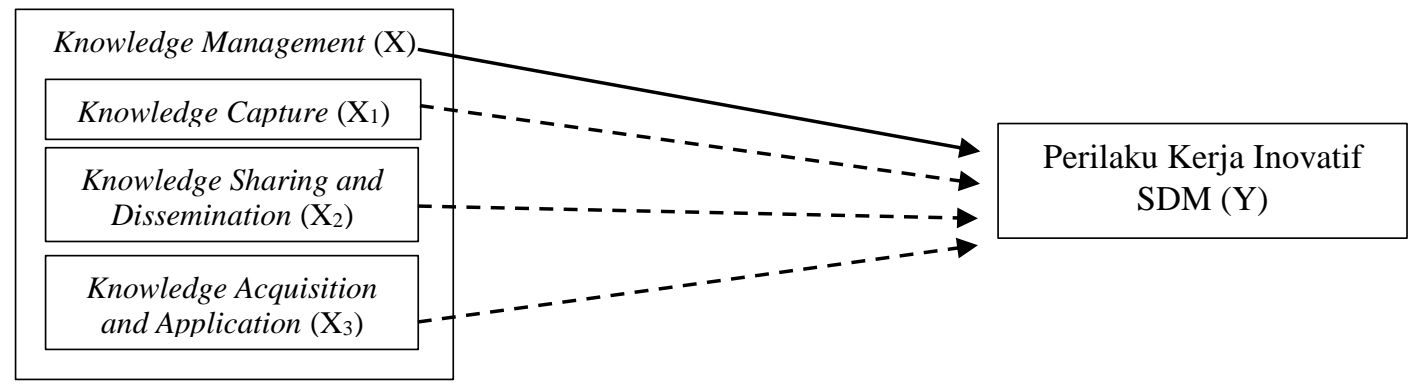

Gambar 1.

Paradigma Penelitian

\section{KERANGKA TEORI}

\section{Knowledge Management}

Pengetahuan semakin diakui sebagai aset yang penting dari organisasi. Paradigma paling baru adalah pengetahuan sebagai kekuatan, oleh karena itu pengetahuan harus dikelola dan dikreasikan dengan baik oleh organisasi. Nonaka mendefinisikan Knowledge Management sebagai proses kreasi pengetahuan dimana pada awalnya pengetahuan yang tacit (diam-diam) menjadi pengetahuan yang explicit (berwujud) (Nonaka et al., 2018:3-4). Secara teknis, Uriarte (2008:13) menyatakan bahwa Knowledge Management adalah proses manajerial ketika organisasi pembelajar menghasilkan nilai dari aset berbasis intelektual dan pengetahuan mereka, melalui pengidentifikasian, pemerolehan, pendistribusian, dan pemeliharaan sehingga dapat mengelola pengetahuan tidak berbentuk menjadi berbentuk. Sebagai proses manajerial, Knowledge Management membantu organisasi dalam mengelola dan membagi pengetahuan melalui aktivitas praktik SDM sehingga pengetahuan tersebut tidak hilang dan menjadi aset yang dimiliki organisasi. Proses manajerial yang dimaksud menurut Dalkir (2013:43) adalah suatu langkah untuk menangkap, mengorganisasikan, dan penyimpanan pengetahuan serta pengalaman dari setiap individu atau kelompok SDM dalam organisasi dan membuat pengetahuan tersedia untuk individu atau kelompok lainnya. 
Langkah tersebut merupakan koordinasi yang disengaja dan sistematis dari SDM, proses, dan teknologi untuk menambah nilai melalui penggunaan kembali ilmu pengetahuan dan inovasi. Koordinasi ini didasarkan atas siklus terintegrasi dari tiga tahapan yaitu Knowledge Capture (Penciptaan Pengetahuan), Knowledge Sharing and Dissemination (Berbagi dan Transfer Pengetahuan) dan Knowledge Acquisition and Application (Akuisisi dan Aplikasi Pengetahuan) (Dalkir, 2013:43).

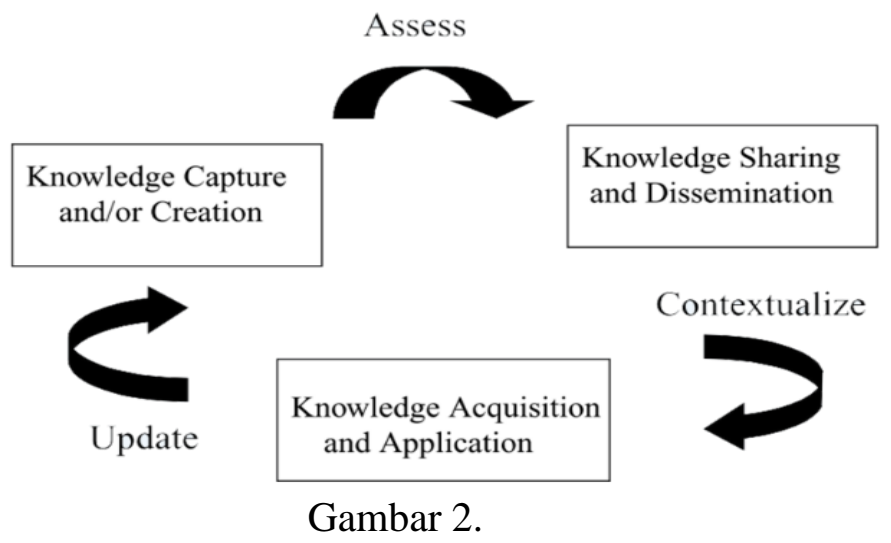

Siklus Terintegrasi Knowledge Management (Sumber: Dalkir, 2013:43)

\section{Knowledge Capture}

Knowledge Capture atau penciptaan pengetahuan merupakan sebuah aktivitas yang dilakukan organisasi dalam menangkap dan menambahkan sebuah pengetahuan baru (Nurul \& Dhiani, 2015:56). Dalam manajemen pengetahuan, penciptaan pengetahuan dilakukan oleh individu yang bekerja di organisasi atau kelompok dalam organisasi. Penciptaan pengetahuan dilakukan dengan membagi persepsi dan menginterpretasikan informasi, kejadian, dan pengalaman secara bersamaan sehingga menjadi sebuah pengetahuan (Dalkir, 2013:78-79). Nonaka et al. (2018:5-7) menyatakan bahwa dimensi penciptaan pengetahuan melibatkan proses konversi pengetahuan melalui interaksi individu dalam organisasi antara pengetahuan tacit dan pengetahuan explicit dengan empat metode, yaitu sosialisai, eksternalisasi, internalisasi, kombinasi. Keempat metode konversi pengetahuan ini merupakan "motor" dari keseluruhan proses penciptaan pengetahuan, kemudian menjadi spiral pengetahuan.
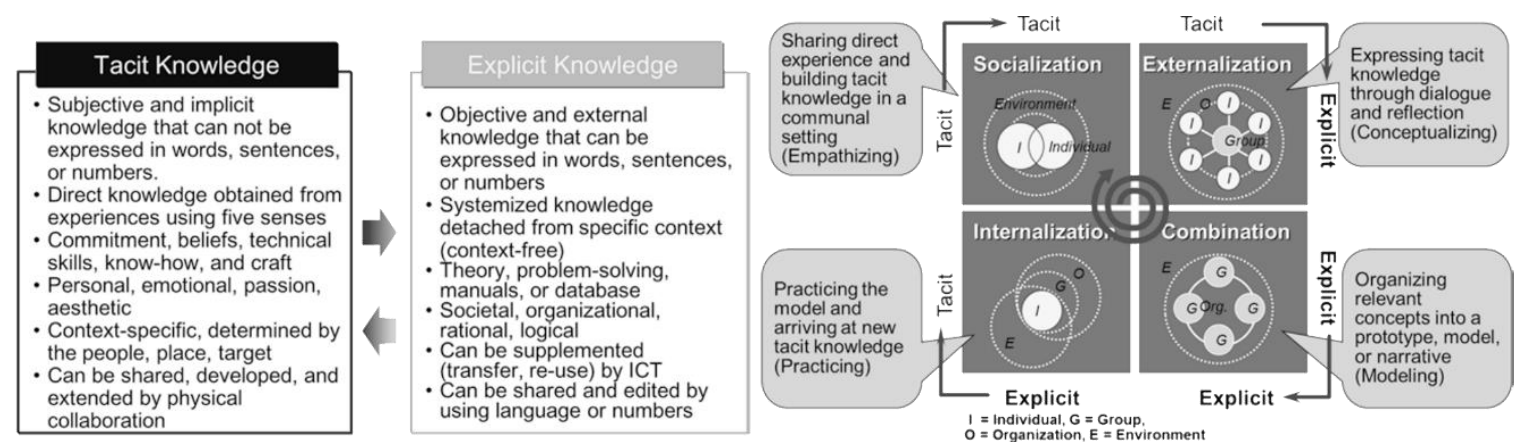

Gambar 3.

Dua tipe pengetahuan dan Spiral Pengetahuan (Sumber: Nonaka et al., 2018:4-6) 


\section{Knowledge Sharing and Dissemination}

Dalkir menyatakan bahwa Knowledge Sharing and Dissemination (berbagi dan diseminasi pengetahuan) dalam organisasi diawali dari interaksi sosial dalam lingkungan kerja, antar individu maupun kelompok (Dalkir, 2013:112). Interaksi tersebut mengacu pada pertukaran pengetahuan antara individu, tim, unit organisasi, dan keseluruhan organisasi, mereka mengomunikasikan pengetahuan dan mengasimilasi pengetahuan dalam interaksinya (Schwartz, 2006:493). Lebih lanjut, Dalkir menjelaskan bahwa berbagi pengetahuan juga merupakan aktivitas dalam organisasi yang tidak hanya dibatasi dengan menyediakan akses data dan dokumen, melainkan harus terjadi hubungan yang menghasilkan pengetahuan dan yang menggunakannya sehingga pengetahuan tidak hanya dibagi, tetapi terjadi diseminasi (Dalkir, 2013:112). Terdapat beberapa faktor yang mempengaruhi berbagi pengetahuan, antara lain (1) Motivasi, munculnya dorongan agar individu inisiatif menampilkan pengetahuan dalam bentuk keahlian atau keterampilan dalam kerja. (2) Kemampuan menyerap pengetahuan, pentingnya individu memiliki kemampuan menangkap pengetahuan membuat individu lain lebih leluasa dalam berbagi pengetahuan. (3) Kekayaan saluran, saluran memfasilitasi individu dalam berbagi pengetahuannya seperti media komunikasi agar mudah terhubung. (4) Sense of self wort, penilaian tinggi terhadap individu yang mampu berbagi pengetahuan. (5) In role behavior, peran individu di lingkungan kerja dalam berbagi pengetahuan. (6) Sikap berbagi pengetahuan, perilaku individu dalam menyebarkan pengetahuan yang dimilikinya dengan individu lain dalam organisasi (Nurul \& Dhiani, 2015:79-84).

\section{Knowledge Acquisition and Application}

Menurut Dalkir, Knowledge Acquisition and Application (akuisisi dan pengaplikasian pengetahuan) adalah penggunaan atau implementasi kembali pengetahuan, yaitu pengetahuan tersebut tersedia di sebuah wadah sebagai tempat disimpannya pengetahuan menjadi sebuah bentuk. Sehingga pengetahuan pada akhirnya dapat diakses dan digunakan oleh semua, individu maupun kelompok dalam organisasi (Dalkir, 2013:146). Penggunaan kembali pengetahuan memiliki 2 dimensi, yaitu dimensi pada individu dan dimensi pada kelompok dan organisasi (Nurul \& Dhiani, 2015:100-101).

\section{Perilaku Kerja Inovatif SDM}

De Jong dan Den Hartog (2010:24) menyatakan Perilaku Kerja Inovatif SDM adalah upaya tingkah laku pegawai yang muncul atas dasar kreatifitas yang dimilikinya sehingga dapat menjadikan perilaku organisasi lebih inovatif. Lebih lanjut Khodakarami dan Zakaria (2015:162) menyatakan perilaku yang dimaksud bertujuan untuk mencapai inisiasi dan pengenalan yang disengaja dalam peran kerja, ide, proses, produk atau prosedur baru yang bermanfaat dalam hal ini untuk mencapai tujuan Knowledge Management. Dikutip dari Zhou dan Velamuri (2018:3-6) setidaknya terdapat beberapa faktor yang mempengaruhi perilaku kerja inovatif SDM sebagai berikut: (1) Kepemimpinan. Pemimpin yang mendukung penuh dalam berinovasi kepada pegawainya dapat mempengaruhi munculnya perilaku kerja inovatif dalam organisasi. Dalam hal ini, pemimpin melakukan komunikasi secara efektif kepada pegawai untuk mentransfer, konsep maupun informasi terkait pengetahuan dengan tepat. (2) Karakteristik Pekerjaan. Pegawai yang telah familiar dan terbiasa dengan tugas-tugas yang ada akan mudah menemukan tips kerja. Oleh karena itu, pengetahuan mudah didapatkan pegawai ketika dihadapkan dengan tugas-tugas kerja. (3) Grup dan Jaringan. Hubungan interpersonal yang baik dan tingkat kepercayaan yang tinggi pada kelompok akan menyebabkan perasaan pegawai lebih aman untuk menyuarakan ide- 
ide terkait pengetahuan mereka secara terbuka. (4) Visi Misi Bersama dalam Organisasi. Visi dan misi organisasi pembelajar yang mengarah pada manajemen pengetahuan dapat mewujudkan budaya inovatif pegawainya agar mencapai sasaran yang telah ditentukan bersama.

\section{HASIL DAN PEMBAHASAN}

\section{Uji Validitas dan Reliabilitas Instrumen}

Sebelum disebarkan ke Balai Diklat Keuangan Yogyakarta, kuesioner yang diadaptasi harus diujicobakan terlebih dahulu. Uji validitas reliabilitas tryout dan langsung ke seluruh sampel dianalisis menggunakan bantuan software IBM SPSS Statistics Pengambilan keputusan tryout uji validitas item pernyataan kuesioner dengan membandingkan nilai $\mathrm{r}$ hitung dengan nilai $\mathrm{r}$ tabel pada taraf probabilitas signifikansi $0,05(5 \%)$ dengan $\mathrm{N}=28(\mathrm{df}=$ $\mathrm{N}-2=30-2$ ) yaitu sebesar 0,374 . Jika koefisien korelasi (rxy) $\geq 0,374$ item-item pernyataan dinyatakan valid. Selain itu, uji reliabilitas dalam penelitian ini dengan koefisien Cronbach's Alpha. Suatu kuesioner dinyatakan reliabel jika koefisien Cronbach's Alpha $\geq$ 0,6 . Setelah melakukan uji coba (tryout) dengan 30 sampel didapat 40 item pernyataan yang valid dan 5 item pernyataan yang tidak valid, sehingga 40 item pernyataan dapat digunakan dalam penelitian ini dan 5 item pernyataan digugurkan.

Setelah melakukan tryout, peneliti langsung menguji validitas dan reliabilitas 40 item yang dapat digunakan. Hasil olah data uji validitas yang telah dilakukan diperoleh nilai $r$ hitung untuk seluruh item pernyataan tiap-tiap variabel lebih besar dari nilai $r$ tabel yang sudah ditentukan melalui tabel distribusi nilai $r$ tabel pada 31 responden yaitu 0,355. Dengan demikian, seluruh item kuesioner yang diuji langsung kepada responden di Balai Diklat Keuangan Yogyakarta dinyatakan valid karena nilai $r$ hitung lebih besar daripada nilai $r$ tabel. Uji reliabilitas terhadap 4 variabel yang diuji menunjukkan nilai Cronbach Alpha sebesar 0,971. Maka dari hasil uji reliabilitas tersebut dapat disimpulkan bahwa seluruh item pernyataan pada kuesioner penelitian ini dinyatakan reliabel karena nilai Cronbach's Alpha dari seluruh item pernyataan lebih besar daripada nilai ketentuannya yaitu 0,6.

\section{Analisis Data Deskriptif Responden dan Analisis Deskriptif Statistik}

Setelah proses tryout uji validitas dan reliabilitas kuesioner, peneliti mulai menyebarkan kuesioner langsung kepada responden di Balai Diklat Keuangan Yogyakarta. Namun, hanya 31 kuesioner saja yang dapat dikumpulkan. Oleh karena itu penyebaran kuesioner hanya meliputi 31 pegawai ASN sebagai responden. Berikut ini adalah hasil analisis data deskriptif responden dan analisis statistik deskriptif.

Tabel 2.

Distribusi Data Responden.

\begin{tabular}{clc}
\hline No & \multicolumn{1}{c}{ Bagian } & Jumlah Pegawai \\
\hline 1 & Sub Bagian Umum dan Kepatuhan & 11 \\
2 & Internal & 8 \\
3 & Seksi Penyelenggara & 6 \\
4 & Seksi Evaluasi dan Informasi & 6 \\
& $\quad$ Jidyaiswara & 31 \\
\hline
\end{tabular}

Sumber: data kepegawaian BDK Yogyakarta, diolah (2020) 
Pada tabel 2, berdasarkan data responden yang terkumpul dapat dikelompokkan menjadi tiga karakteristik, yang pertama adalah karakteristik berdasarkan jenis kelamin. Dari 31 orang responden yang menjadi pegawai di Balai Diklat Keuangan Yogyakarta terdiri dari 20 orang responden laki-laki $(64 \%)$ dan 11 orang responden perempuan (36\%). Hal ini menunjukkan bahwa jumlah responden laki-laki hanya memiliki selisih 9 saja dengan responden perempuan. Kedua, ditinjau dari karaktreristik berdasarkan usia, responden yang paling banyak berada pada range umur 41 sampai 50 tahun, yaitu sebanyak 14 orang dengan tingkat persentase $45 \%$. Sedangkan karyawan yang paling sedikit berada pada range umur $>51$ tahun, yaitu sebanyak 3 orang dengan tingkat persentase 9\% dari keseluruhan responden. Ketiga adalah karakteristik berdasarkan pendidikan terakhir. Responden yang paling banyak berada pada pendidikan terakhir di tingkat Sarjana Strata 1 berjumlah 10 orang dengan persentase 32,2\%. Responden dengan tingkat pendidikan Diploma 1 dan Diploma 4 masing-masing terdapat 1 orang dengan persentase 3,2\%. Selain itu, terdapat pendidikan terakhir yang tidak diisi oleh responden berjumlah 2 orang dengan persentase $6,4 \%$.

Tabel 3.

Analisis Deskriptif Statistik

Descriptive Statistics

\begin{tabular}{llllll}
\hline & $\mathrm{N}$ & Minimum & Maximum & Mean & Std. Deviation \\
\hline KC & 31 & 20.00 & 30.00 & 24.9032 & 2.67525 \\
KS & 31 & 37.00 & 54.00 & 46.5161 & 4.84335 \\
KA & 31 & 18.00 & 30.00 & 24.7419 & 3.04377 \\
PKISDM & 31 & 51.00 & 85.00 & 70.1290 & 8.86845 \\
Valid N (listwise) & 31 & & & & \\
\hline
\end{tabular}

Sumber: data primer, diolah (2020)

Pada tabel 3 dapat dilihat bahwa variabel Knowledge Capture (KC) memiliki nilai terendah sebesar 20,00 dan nilai tertinggi sebesar 30,00 dengan nilai rata-ratanya sebesar 24,90 dan standar deviasinya (tingkat sebaran datanya) sebesar 2,67. Variabel Knowledge Sharing and Dissemination (KS) memiliki nilai terendah sebesar 37,00 dan nilai tertinggi sebesar 54,00 dengan nilai rata-ratanya sebesar 46,51 dan tingkat sebaran datanya sebesar 4,84. Variabel Knowledge Acquisition and Application (KA) memiliki nilai terendah sebesar 18,00 dan nilai tertinggi sebesar 30,00 dengan nilai rata-ratanya sebesar 24,74 dan tingkat sebaran datanya sebesar 3,04. Variabel Perilaku Kerja Inovatif SDM (PKISDM) memiliki nilai terendah sebesar 51,00 dan nilai tertinggi sebesar 85,00 dengan nilai rata-ratanya sebesar 70,13 dan tingkat sebaran datanya sebesar 8,89.

\section{Analisis Outer Model (Model Pengukuran) \\ Convergent Validity}

Convergent Validity dilakukan dengan melihat item reliability (indikator validitas) yang ditunjukkan oleh nilai loading factor. Jika nilai loading factor lebih besar 0,7 dapat dinyatakan valid. Pada penelitian ini pengujian Convergent Validity dilakukan 2 tahap dikarenakan pada tahap pertama terdapat beberapa item yang tidak valid. Tabel 4 menunjukkan hasil nilai loading factor 2 tahap dari tiap-tiap indikator dalam item pertanyaan.

Dapat dibuktikan pada tabel 4 bahwa terdapat 9 item yaitu X1.1, X1.6, X2.1, X2.5, $\mathrm{X} 2.6, \mathrm{X} 2.7, \mathrm{X} 2.8, \mathrm{Y} 10$, dan Y16 dinyatakan gugur karena nilai outer loading tidak memenuhi ketentuan yaitu $<0.7$. Oleh karena itu, pengujian kedua dilakukan dengan item 
yang memenuhi ketentuan saja, dengan kata lain nilai outer loading $>0.7$. Pada tahap kedua terdapat beberapa nilai outer loading tiap - tiap item berubah, ada yang mengalami peningkatan nilai dan ada yang mengalami penurunan nilai setelah 9 item digugurkan di tahap pertama. Selain itu terdapat item yang tidak berubah nilainya dari tahap pertama.

Tabel 4.

Hasil Nilai Outer Loading

\begin{tabular}{|c|c|c|c|}
\hline Variabel & $\begin{array}{c}\text { Indikator } \\
\text { (Item) }\end{array}$ & $\begin{array}{c}\text { Nilai Outer Loading } \\
\text { (Tahap Pertama) }\end{array}$ & $\begin{array}{c}\text { Nilai Outer Loading } \\
\text { (Tahap Kedua) }\end{array}$ \\
\hline \multirow[t]{6}{*}{ X1 (Knowledge Capture) } & $\mathrm{X} 1.1$ & $0.660^{*}$ & Gugur \\
\hline & $\mathrm{X} 1.2$ & 0.718 & 0.757 \\
\hline & $\mathrm{X} 1.3$ & 0.733 & 0.711 \\
\hline & $\mathrm{X} 1.4$ & 0.824 & 0.850 \\
\hline & $\mathrm{X} 1.5$ & 0.757 & 0.812 \\
\hline & $\mathrm{X} 1.6$ & $0.645 *$ & Gugur \\
\hline \multirow{10}{*}{$\begin{array}{l}\mathrm{X} 2 \text { (Knowledge Sharing } \\
\text { and Dissemination) }\end{array}$} & $\mathrm{X} 2.1$ & $0.543 *$ & Gugur \\
\hline & $\mathrm{X} 2.2$ & 0.747 & 0.785 \\
\hline & $\mathrm{X} 2.3$ & 0.714 & 0.772 \\
\hline & $\mathrm{X} 2.4$ & 0.755 & 0.805 \\
\hline & $\mathrm{X} 2.5$ & $0.627 *$ & Gugur \\
\hline & $\mathrm{X} 2.6$ & $0.021 *$ & Gugur \\
\hline & $\mathrm{X} 2.7$ & $0.573 *$ & Gugur \\
\hline & $\mathrm{X} 2.8$ & $0.625 *$ & Gugur \\
\hline & $\mathrm{X} 2.9$ & 0.709 & 0.729 \\
\hline & $\mathrm{X} 2.10$ & 0.745 & 0.749 \\
\hline \multirow{7}{*}{$\begin{array}{l}\mathrm{X} 3 \text { (Knowledge Acquisition } \\
\text { and Application) }\end{array}$} & $\mathrm{X} 3.1$ & 0.790 & 0.790 \\
\hline & $\mathrm{X} 3.2$ & 0.791 & 0.790 \\
\hline & $\mathrm{X} 3.3$ & 0.764 & 0.764 \\
\hline & $\mathrm{X} 3.4$ & 0.819 & 0.819 \\
\hline & $\mathrm{X} 3.5$ & 0.933 & 0.933 \\
\hline & X3.6 & 0.795 & 0.796 \\
\hline & $\mathrm{X} 3.7$ & 0.868 & 0.868 \\
\hline \multirow{7}{*}{$\begin{array}{l}\text { Y (Perilaku Kerja Inovatif } \\
\text { SDM) }\end{array}$} & $\mathrm{Y} 1$ & 0.849 & 0.856 \\
\hline & $\mathrm{Y} 2$ & 0.812 & 0.820 \\
\hline & Y3 & 0.799 & 0.803 \\
\hline & Y4 & 0.762 & 0.779 \\
\hline & Y5 & 0.774 & 0.780 \\
\hline & Y6 & 0.806 & 0.804 \\
\hline & Y7 & 0.821 & 0.832 \\
\hline \multirow{10}{*}{$\begin{array}{l}\text { Y (Perilaku Kerja Inovatif } \\
\text { SDM) }\end{array}$} & Y8 & 0.886 & 0.886 \\
\hline & Y9 & 0.827 & 0.820 \\
\hline & Y10 & $0.687 *$ & Gugur \\
\hline & Y11 & 0.860 & 0.852 \\
\hline & Y12 & 0.787 & 0.778 \\
\hline & Y13 & 0.783 & 0.781 \\
\hline & Y14 & 0.777 & 0.777 \\
\hline & Y15 & 0.844 & 0.840 \\
\hline & Y16 & $0.683^{*}$ & Gugur \\
\hline & Y17 & 0.800 & 0.797 \\
\hline
\end{tabular}

* Item yang digugurkan.

Sumber: data primer, diolah (2020)

\section{Discriminant Validity}

Uji ini dilakukan dengan cara melihat nilai cross loading pengukuran konstruk. Model pengukuran memiliki discriminant validity yang baik apabila korelasi antara konstruk dengan indikatornya lebih tinggi daripada korelasi dengan indikator dari konstruk lainnya. Dari tabel hasil nilai cross loading di bawah ini didapatkan keseluruhan dari konstruk 
pembentuk dinyatakan memiliki diskriminan yang baik. Dimana masing-masing konstruk memiliki hubungan tertinggi dengan variabelnya sendiri.

Tabel 5.

Hasil Nilai Discriminant Validity

\begin{tabular}{|c|c|c|c|c|}
\hline & $\begin{array}{c}\mathrm{X} 1 \\
\text { (Knowledge } \\
\text { Capture) }\end{array}$ & $\begin{array}{c}\mathrm{X} 2 \\
\text { (Knowledge } \\
\text { Sharing and } \\
\text { Dissemination) }\end{array}$ & $\begin{array}{c}\mathrm{X} 3 \\
\text { (Knowledge } \\
\text { Acquisition } \\
\text { and } \\
\text { Application) }\end{array}$ & $\begin{array}{c}\text { Y (Perilaku } \\
\text { Kerja } \\
\text { Inovatif } \\
\text { SDM) } \\
\end{array}$ \\
\hline $\mathrm{X} 1.2$ & 0.757 & 0.449 & 0.562 & 0.456 \\
\hline X1.3 & 0.711 & 0.608 & 0.475 & 0.254 \\
\hline X1.4 & 0.850 & 0.674 & 0.671 & 0.479 \\
\hline X1.5 & 0.812 & 0.609 & 0.567 & 0.507 \\
\hline $\mathrm{X} 2.2$ & 0.533 & 0.785 & 0.609 & 0.579 \\
\hline $\mathrm{X} 2.3$ & 0.733 & 0.772 & 0.574 & 0.500 \\
\hline X2.4 & 0.660 & 0.805 & 0.671 & 0.615 \\
\hline X2.9 & 0.461 & 0.729 & 0.396 & 0.478 \\
\hline $\mathrm{X} 2.10$ & 0.436 & 0.749 & 0.593 & 0.524 \\
\hline X3.1 & 0.480 & 0.684 & 0.790 & 0.581 \\
\hline X3.2 & 0.695 & 0.602 & 0.790 & 0.584 \\
\hline X3.3 & 0.651 & 0.456 & 0.764 & 0.551 \\
\hline X3.4 & 0.622 & 0.586 & 0.819 & 0.808 \\
\hline X3.5 & 0.656 & 0.782 & 0.933 & 0.796 \\
\hline X3.6 & 0.449 & 0.44 & 0.796 & 0.570 \\
\hline X3.7 & 0.667 & 0.714 & 0.868 & 0.681 \\
\hline Y.1 & 0.504 & 0.580 & 0.735 & 0.856 \\
\hline Y.2 & 0.450 & 0.473 & 0.684 & 0.820 \\
\hline Y.3 & 0.601 & 0.774 & 0.649 & 0.803 \\
\hline Y.4 & 0.525 & 0.598 & 0.605 & 0.779 \\
\hline Y.5 & 0.300 & 0.439 & 0.522 & 0.780 \\
\hline Y.6 & 0.362 & 0.475 & 0.531 & 0.804 \\
\hline \multirow[t]{2}{*}{ Y.7 } & 0.394 & 0.530 & 0.701 & 0.832 \\
\hline & $\begin{array}{c}\mathrm{X} 1 \\
\text { (Knowledge } \\
\text { Capture) }\end{array}$ & $\begin{array}{c}\mathrm{X} 2 \\
\text { (Knowledge } \\
\text { Sharing and } \\
\text { Dissemination) }\end{array}$ & $\begin{array}{c}\mathrm{X} 3 \\
\text { (Knowledge } \\
\text { Acquisition } \\
\text { and } \\
\text { Application) }\end{array}$ & $\begin{array}{c}\text { Y (Perilaku } \\
\text { Kerja } \\
\text { Inovatif } \\
\text { SDM) }\end{array}$ \\
\hline Y.8 & 0.488 & 0.685 & 0.797 & 0.886 \\
\hline Y.9 & 0.542 & 0.562 & 0.698 & 0.820 \\
\hline Y.11 & 0.442 & 0.647 & 0.652 & 0.852 \\
\hline Y.12 & 0.417 & 0.467 & 0.687 & 0.778 \\
\hline Y.13 & 0.352 & 0.506 & 0.596 & 0.781 \\
\hline Y.14 & 0.346 & 0.525 & 0.626 & 0.777 \\
\hline Y.15 & 0.505 & 0.667 & 0.681 & 0.840 \\
\hline Y.17 & 0.620 & 0.631 & 0.611 & 0.797 \\
\hline
\end{tabular}

Sumber: data primer, diolah (2020)

Berdasarkan sajian data pada tabel 5 di atas dapat diketahui bahwa setiap item pada variabel penelitian memiliki nilai cross loading terbesar pada variabel yang dibentuknya dibandingkan dengan nilai cross loading pada item lainnya. Berdasarkan hasil yang 
diperoleh tersebut, dapat dinyatakan bahwa indikator-indikator yang digunakan dalam penelitian ini telah memiliki discriminant validity yang baik dalam menyusun variabelnya masing-masing.

\section{Average Variance Extracted (AVE)}

Selain mengamati nilai cross loading, discriminant validity juga dapat diketahui melalui metode lainnya yaitu dengan melihat nilai average variant extracted (AVE) untuk tiap-tiap variabel dipersyaratkan nilainya harus $>0,5$ untuk model yang baik.

Tabel 6.

Nilai Average Variance Extracted (AVE)

\begin{tabular}{lcc}
\hline & $\begin{array}{c}\text { Average Variance } \\
\text { Extracted (AVE) }\end{array}$ & $\begin{array}{c}\text { Akar Kuadrat Average } \\
\text { Variance Extracted (AVE) }\end{array}$ \\
\hline X1 (Knowledge Capture) & 0.615 & 0.784 \\
X2 (Knowledge Sharing and & 0.590 & 0.768 \\
$\begin{array}{l}\text { Dissemination) } \\
\text { X3 (Knowledge Acquisition and }\end{array}$ & 0.680 & 0.825 \\
Application) & & 0.814 \\
Y (Perilaku Kerja Inovatif SDM) & 0.663 & \\
\hline
\end{tabular}

Sumber: data primer, diolah (2020)

Tabel 7.

Nilai Korelasi Average Variance Extracted (AVE) Pada Output Fornell-Larcker.

\begin{tabular}{|c|c|c|c|c|}
\hline & $\begin{array}{c}\mathrm{X} 1 \\
\text { (Knowledge } \\
\text { Capture) }\end{array}$ & $\begin{array}{c}\mathrm{X} 2 \\
\text { (Knowledge } \\
\text { Sharing and } \\
\text { Dissemination) }\end{array}$ & $\begin{array}{c}\mathrm{X} 3 \\
\text { (Knowledge } \\
\text { Acquisition } \\
\text { and } \\
\text { Application) }\end{array}$ & $\begin{array}{l}\text { Y (Perilaku } \\
\text { Kerja } \\
\text { Inovatif } \\
\text { SDM }\end{array}$ \\
\hline X1 (Knowledge Capture) & 0.784 & & & \\
\hline $\begin{array}{l}\mathrm{X} 2 \text { (Knowledge Sharing } \\
\text { and Dissemination) }\end{array}$ & 0.737 & 0.768 & & \\
\hline $\begin{array}{l}\text { X3 (Knowledge } \\
\text { Acquisition and } \\
\text { Application) }\end{array}$ & 0.733 & 0.748 & 0.825 & \\
\hline $\begin{array}{l}\text { Y (Perilaku Kerja Inovatif } \\
\text { SDM }\end{array}$ & 0.564 & 0.706 & 0.807 & 0.814 \\
\hline
\end{tabular}

Sumber: data primer, diolah (2020)

Berdasarkan tabel 6 dan 7 di atas dapat dibuktikan bahwa nilai AVE variabel Knowledge Capture, Knowledge Sharing and Dissemination, Knowledge Acquisition and Application dan Perilaku Kerja Inovatif SDM lebih besar dari 0,5. Selain itu, nilai akar kuadrat AVE untuk setiap variabel lebih besar daripada nilai korelasinya sehingga dapat dinyatakan bahwa setiap variabel telah memiliki discriminant validity yang baik.

\section{Composite Reliability}

Pengujian ini digunakan untuk menentukan tingkat reliabilitas keseluruhan variabel. Uji reliabilitas dengan composite reliability yang ditentukan dengan melihat nilai cronbach alpha. Suatu variabel dapat dinyatakan reliabel apabila memiliki nilai cronbach alpha $>0.7$. 
Tabel 8.

Composite Reliability

\begin{tabular}{lc}
\hline \multicolumn{1}{c}{ Variabel } & Nilai Composite Reliability \\
\hline X1 (Knowledge Capture) & 0.864 \\
X2 (Knowledge Sharing and & 0.878 \\
Dissemination) & \\
X3 (Knowledge Acquisition and & 0.937 \\
Application) & \\
Y (Perilaku Kerja Inovatif SDM) & 0.967 \\
\hline
\end{tabular}

Sumber: data primer, diolah (2020)

Hasil menunjukkan bahwa nilai composite reliability untuk seluruh variabel berada di atas ketentuan, yaitu > 0.7. Dengan nilai yang dihasilkan tersebut seluruh variabel dinyatakan memiliki tingkat reliabilitas yang tinggi.

\section{Analisis Inner Model (Model Struktural)}

Uji Koefisien Determinasi ( $R$ Square)

Tabel 9.

Koefisien Determinasi ( $R$ Square)

\begin{tabular}{cc}
\hline Variabel & Nilai $R$ Square \\
\hline Y (Perilaku Kerja Inovatif SDM) & 0.688 \\
\hline
\end{tabular}

Sumber: data primer, diolah (2020)

Nilai $R$-square pada Tabel 9 menunjukkan bahwa seluruh indikator dari ketiga variabel Knowledge Management, yaitu Knowledge Capture, Knowledge Sharing and Dissemination, dan Knowledge Acquisition and Application secara bersamaan mampu menjelaskan variabel Perilaku Kerja Inovatif SDM sebesar 0.688 atau pada persentase $68,8 \%$ yang mengindikasikan bahwa pengaruh hipotesis mayor berada pada tahap substansial (kuat), dan sisanya sebesar 31,2\% diterangkan oleh indikator lainnya di luar yang diteliti dalam penelitian ini.

\section{Pengujian Hipotesis}

Pengujian hipotesis melalui hasil Path Coefficients dilakukan dengan ketentuan jika nilai $T$ Statistic yang dihasilkan lebih besar dari 1.96 dan nilai $P$ Value yang lebih kecil dari 0.05 hipotesis dapat dinyatakan diterima karena memiliki pengaruh positif dan signifikan. Nilai pengujian hipotesis penelitian ini dapat ditunjukkan pada Tabel 10 dan untuk hasil model penelitian ini dapat digambarkan seperti tampak pada Gambar 4. 


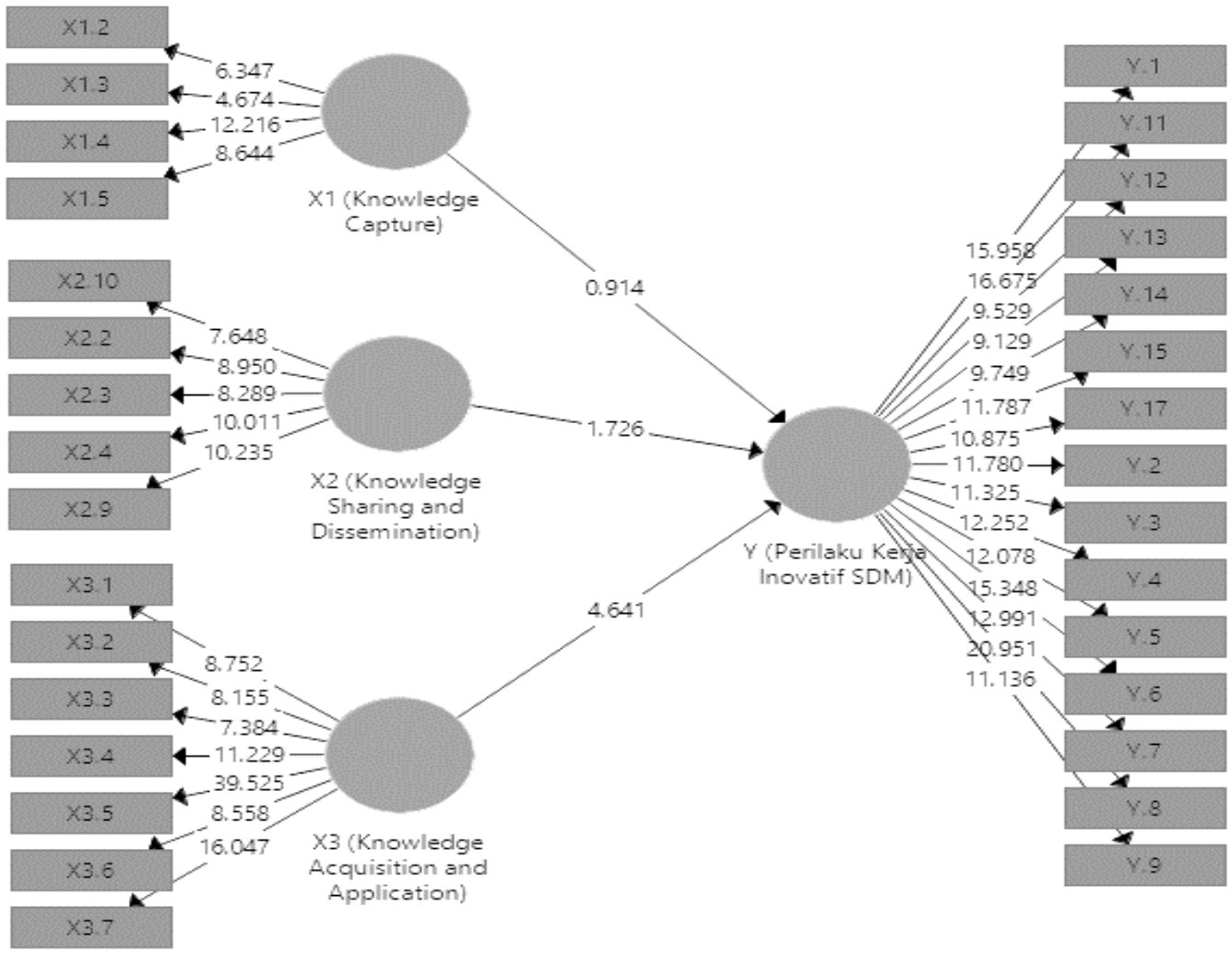

Gambar 4.

Inner Model (Sumber: data primer, diolah 2020)

Tabel 10.

Hasil Path Coefficients

\begin{tabular}{cccccc}
\hline Hipotesis & $\begin{array}{c}\text { Original } \\
\text { Sample (O) }\end{array}$ & $\begin{array}{c}\text { Sample } \\
\text { Mean (M) }\end{array}$ & $\begin{array}{c}\text { Standard } \\
\text { Deviation } \\
\text { (STDEV) }\end{array}$ & $\begin{array}{c}\text { T Statistics } \\
(|\mathrm{O} / \mathrm{STDEV}|)\end{array}$ & P Values \\
\hline X1 -> Y & -0.187 & -0.160 & 0.204 & $0.914^{*}$ & $0.361^{*}$ \\
X2 -> Y & 0.314 & 0.319 & 0.182 & $1.726^{*}$ & $0.085^{*}$ \\
X3 -> Y & 0.709 & 0.691 & 0.153 & 4.641 & 0.000 \\
\hline
\end{tabular}

* Hipotesis ditolak.

Sumber: data primer, diolah (2020).

Pada hipotesis minor 1, variabel $\mathrm{X}_{1}$ (Knowledge Capture) terhadap Y (Perilaku Kerja Inovatif SDM) ternyata tidak memiliki pengaruh yang positif dan signifikan, dikarenakan hasil nilai T Statistic 0.914 di bawah atau lebih kecil dari ketentuan kriteria yaitu $<1.96$ serta nilai $\mathrm{P}$ Value yang dihasilkan sebesar 0.361 , lebih besar dari 0.05 . Maka dari itu hipotesis minor 1 pada penelitian ini dinyatakan ditolak.

Pada hipotesis minor 2, variabel $\mathrm{X}_{2}$ (Knowledge Sharing and Dissemination) tidak memiliki pengaruh yang positif, dan signifikan terhadap variabel Y (Perilaku Kerja Inovatif SDM) dikarenakan nilai T Statistic yang dihasilkan lebih kecil dari 1.96 yaitu sebesar 1.726. 
Selain itu hasil $P$ Value yang dihasilkan lebih besar dari 0.05 yaitu sebesar 0.085 . Maka dari itu hipotesis minor 2 pada penelitian ini dinyatakan ditolak.

Pada hipotesis minor 3, variabel $\mathrm{X}_{3}$ (Knowledge Acquisition and Application) memiliki pengaruh yang positif dan signifikan terhadap variabel Y (Perilaku Kerja Inovatif SDM) dikarenakan hasil T Statistic sebesar 4.641 lebih besar dari 1.96. Nilai $P$ Value yang dihasilkan yaitu 0.000 lebih kecil dari 0.05 . Oleh karena itu, hipotesis minor 3 pada penelitian ini dapat dinyatakan diterima.

\section{Interpretasi Pengujian Hipotesis}

Hipotesis mayor (Pengaruh Knowledge Management terhadap Perilaku Kerja Inovatif SDM di Balai Diklat Keuangan Yogyakarta)

Nilai output $R$-square pada tabel 9 menunjukkan angka sebesar 0.688 yang berarti siklus terintegrasi Knowledge Management berpengaruh secara bersamaan terhadap Perilaku Kerja Inovatif SDM. Hasil penelitian Rahimi et al. (2017:71-72) menjelaskan bahwa aktivitas Knowledge Management seperti mengumpulkan, mengelola, berbagi, belajar, dan menggunakan kembali pengetahuan mengambil peran penting dalam membawa perilaku organisasi menjadi lebih berinovatif, hal ini selaras dengan pembentukan kebiasaan aktivitas Knowledge Management di Balai Diklat Keuangan Yogyakarta menggunakan Kemenkeu Learning Center yang merupakan sebuah aplikasi berbasis web yang dapat menjadi media bagi seluruh pegawai Kementerian Keuangan untuk menyimpan, belajar, dan berbagi ilmu pengetahuan keuangan negara. Karena dengan Kemenkeu Learning Center pegawai dapat berinovasi dalam mengumpulkan, mengelola, berbagi, belajar, menggunakan kembali pengetahuan, baik secara formal melalui kegiatan diklat yang difasilitasi oleh balai maupun secara informal melalui forum-forum komunitas praktisi (Edukasi Keuangan BPPK, 2017:9). Selain itu, dalam menunjang efektivitas praktik dari siklus terintegrasi Knowledge Management untuk mewujudkan Perilaku Kerja Inovatif SDM, Balai Diklat Keuangan Yogyakarta berkomitmen pada penyelarasan payung regulasinya yaitu (1) MenpanRB Nomor 14 Tahun 2011 tentang Pedoman Pelaksanaan Program Knowledge Management; (2) Keputusan Menkeu No.974/KMK.01/2016 tentang Implementasi Inisiatif Strategis Program Reformasi Birokrasi dan Transformasi Kelembagaan Kemenkeu mengatur bahwa salah satu tema sentralnya adalah pembentukan Kemenkeu Corporate University dengan terobosan Knowledge Management untuk mengoptimalkan proses pembelajaran menggantikan metode pembelajaran klasikal; dan (3) Keputusan Kepala BPPK No. KEP-140/PP/2017 tentang Cetak Biru Kemenkeu Corporate University, mengatur bahwa tugas Knowledge Management adalah seluruh pegawai Kemenkeu sebagai SGO (Suharsono, 2018:12).

\section{Hipotesis minor 1 (Pengaruh Knowledge Capture terhadap Perilaku Kerja Inovatif SDM di Balai Diklat Keuangan Yogyakarta)}

Hipotesis ini tidak memiliki pengaruh yang positif dan signifikan dan membuktikan bahwa indikator sosialisasi, eksternalisasi, kombinasi, dan internalisasi tidak mempengaruhi dalam menunjang efektivitas praktik Knowledge Capture. Padahal, dalam menunjang efektivitas praktik Knowledge Management sebagai pilar Kemenkeu Corporate University dalam mewujudkan Perilaku Kerja Inovatif SDM setidaknya terdapat payung regulasi yang mendasarinya yaitu Keputusan Kepala BPPK No. KEP-140/PP/2017 tentang Cetak Biru Kemenkeu Corporate University yang mengatur bahwa tugas Knowledge Management adalah seluruh pegawai Kemenkeu sebagai SGO (Suharsono, 2018:12). Peraturan tersebut tidak terealisasi terhadap fenomena yang didapat peneliti karena Balai Diklat Keuangan 
Yogyakarta pada implementasi Knowledge Capture sebagai siklus terintegrasi dari Knowledge Management hanya memanfaatkan produksi video pembelajaran melalui Kemenkeu Learning Center dan sampai saat ini masih didominasi oleh Widyaiswara saja. Knowledge Capture seharusnya melibatkan interaksi dalam berbagi ide, gagasan, dan tukar pikiran oleh seluruh elemen ASN karena menurut Nonaka, interaksi dalam Knowledge Capture meliputi 4 dimensi sosialisasi, eksternalisasi, kombinasi, internalisasi (Nonaka et al., 2018:5-7) Maka dari itu Knowledge Capture akan memberikan dampaknya dalam mengubah paradigma SDM menjadi ASN Corporate University, ASN juga akan semakin mampu untuk belajar dan melahirkan ide-ide baru yang kreatif dan inovatif bagi keseluruhan elemen. Hal ini baik untuk dilakukan karena bermanfaat untuk meningkatkan koordinasi, mempercepat proses aktivitas kerja dan menumbuhkan budaya belajar di Balai Diklat Keuangan Yogyakarta sehingga paradigma ASN Corporate University akan terwujud melalui perilaku kerja inovatif. Darroch menyatakan bahwa pentingnya perilaku kerja inovatif SDM dalam organisasi pembelajar agar SDM dapat mewujudkan ide-ide inovatif yang berguna bagi seluruh individu lain nya dalam pencapaian interaksi Knowledge Capture (Darroch, 2005:112).

Pada uji instrumen melalui software IBM SPSS Statistic, hasil skor keseluruhan tanggapan responden pada item pertanyaan variabel Knowledge Capture, terdapat item pernyataan dengan skor tertinggi dan terendah. Pada item pertanyaan nomor 1 dengan indikator sosialisasi memiliki skor terbesar dari item pertanyaan lainnya. Indikator sosialisasi dengan mudah memberikan proses dalam bertukar pengetahuan yang ada pada diri pegawai individu ke pegawai individu lain (bersifat tak berwujud). Sedangkan pada item pertanyaan nomor 7 indikator internalisasi memiliki skor paling rendah dari item pertanyaan lain. Dalam penciptaan pengetahuan tak berwujud menjadi berwujud, internalisasi disebut sebagai sebuah proses yang ideal, melalui difusi dan penyatuan perilaku baru dalam menganalisis informasi berupa pengetahuan agar dapat belajar, memahami, dan memberi pengetahuan baru yang lebih dikenal dengan istilah learning by doing (Nonaka et al., 2018). Oleh karena itu, indikator internalisasi perlu ditingkatkan agar ASN dalam lingkup Kementerian Keuangan lebih kritis dalam memperluas, mengembangkan, dan mengubah arahan yang mengacu pada pengetahuan dasar yang sudah dimilikinya.

\section{Hipotesis minor 2 (Pengaruh Knowledge Sharing and Dissemination Terhadap Perilaku Kerja Inovatif SDM di Balai Diklat Keuangan Yogyakarta)}

Pengujian hipotesis minor 2 ternyata tidak memiliki pengaruh yang positif dan signifikan. Hipotesis tersebut tidak konsisten terhadap penelitian terdahulu. Hasil tersebut disebabkan karena Knowledge Sharing and Dissemination dilakukan oleh seluruh pegawai Balai Diklat Keuangan Yogyakarta dengan hanya memfokuskan kepada penggunaan website Kemenkeu Learning Center (KLC), sebuah wadah pengetahuan yang dapat memfasilitasi pegawai SGO dan Widyaiswara untuk memproduksi video pembelajaran keuangan negara. Walaupun pemanfaatan KLC tersebut selaras dengan pernyataan Dalkir bahwa Knowledge Sharing membutuhkan wadah yang disediakan oleh organisasi agar pengetahuan dapat dibagikan dan mengalir dimanapun (Dalkir, 2013:146), ternyata pada aktivitas kerja sehari-hari pegawai Balai Diklat Keuangan Yogyakarta dalam praktik Knowledge Sharing and Dissemination hanya sekedar melakukan sharing dengan tatap muka atau interaksi langsung, seperti pada budaya Apel Pagi yang biasa dilakukan setiap hari. Selain itu, pada penyelenggaraan seminar atau workshop di Balai Diklat Keuangan Yogyakarta yang dilakukan guna menunjang praktik Knowledge Sharing juga belum memberikan pengaruhnya terhadap Perilaku Kerja Inovatif SDM. 
Dengan kata lain, sebenarnya Knowledge Sharing and Dissemination telah diimplementasikan oleh Balai Diklat Keuangan Yogyakarta dan sejalan dengan penelitian Darroch yang menyatakan pengetahuan harus mengalir secara bebas di dalam organisasi karena semakin baik penyebaran pengetahuan, semakin besar kemungkinan inovasi yang dihasilkan (Darroch, 2005:105). Namun implementasi tersebut belum membuktikan pengaruhnya terhadap Perilaku Kerja Inovatif SDM pada pengujian hipotesis ini. Seharusnya praktik-praktik Knowledge Sharing dapat memberikan dampak pada perilaku inovatif pegawai, memberikan pemikiran baru bahwa Knowledge Sharing tidak hanya sampai ke taraf berbagi dan menerima namun memberikan dampak dan pemikiran baru agar inovasi tidak muncul pada penyelenggaraan kegiatan diklat, tetapi tumbuh dalam diri individu pegawai sendiri, karena Abukhait et al. (2018:5-6) menyatakan bahwa Knowledge Sharing sebagai alat yang digunakan untuk menumbuhkan perilaku inovatif dalam diri individu. Knowledge Sharing dapat memfasilitasi kegiatan inovatif dan merangsang pemikiran kritis, yang menghasilkan peningkatan kemampuan dalam menerjemahkan gagasan ke dalam inovasi. Oleh karena itu, praktik Knowledge Sharing di Balai Diklat Keuangan Yogyakarta hanya sampai ke taraf berbagi dan menangkap saja, tidak sampai pada bagaimana pegawai memberikan inovasi praktik Knowledge Sharing dalam aktivitas kerjanya. Pentingnya peningkatan aktivitas Knowledge Sharing dalam upaya mewujudkan Perilaku Kerja Inovatif SDM dapat memberikan kontribusi dalam meningkatkan kemampuan dan kapabilitas pegawai, karena penelitian Asegaff \& Wasitowati (2015:2018) menyatakan bahwa Knowledge Sharing mampu meningkatkan kapabilitas perilaku kerja inovasi pegawai, melalui penemuan ide baru dan metode kerja baru.

\section{Hipotesis Minor 3 (Pengaruh Knowledge Acquisition and Application Terhadap Perilaku Kerja Inovatif SDM di Balai Diklat Keuangan Yogyakarta)}

Uji hipotesis minor 3 pada penelitian ini menunjukkan adanya pengaruh yang positif dan signifikan. Praktik akuisisi dan aplikasi pengetahuan di Balai Diklat Keuangan Yogyakarta dilakukan melalui penggunaan kembali pengetahuan oleh seluruh pegawai untuk mempermudah dalam menyelesaikan tugas-tugas atau pekerjaan sesuai unit kerja atau bagian. Selain itu, penggunaan kembali pengetahuan juga dilakukan pada penyelenggaraan seminar dan diklat. Oleh karena itu, pengetahuan individu yang awalnya tidak berwujud menjadi berwujud dapat terealisasi kembali dalam implementasi pengetahuan untuk menyelesaikan pekerjaan individu bahkan saat penyelenggaraan seminar dan diklat. Hal tersebut mendukung penelitian Lee (2018:3) yang menyatakan bahwa mengakuisisi dan mengaplikasikan pengetahuan menjadi efek terpenting dengan kreativitas dan inovasi organisasi, karena aktivitas berbagi pengetahuan organisasi tidak hanya kembali pada transfer pengetahuan, keterampilan, dan informasi yang efektif, tetapi dapat menunjukkan karakteristik penggunaan pengetahuan tersebut melalui praktik dan implementasi di lingkungan kerja.

\section{E. PENUTUP}

Hasil pengujian hipotesis mayor pada penelitian ini membuktikan bahwa siklus terintegrasi Knowledge Management secara bersamaan mampu mempengaruhi Perilaku Kerja Inovatif SDM di Balai Diklat Keuangan Yogyakarta. Namun pada hasil pengujian hipotesis minor hanya variabel Knowledge Acquisition and Application yang memiliki pengaruh positif dan signifikan terhadap Perilaku Kerja Inovatif SDM di Balai Diklat Keuangan Yogyakarta. Sedangkan untuk variabel Knowledge Capture dan Knowledge 
Sharing and Dissemination belum menunjukkan pengaruhnya terhadap Perilaku Kerja Inovatif SDM di Balai Diklat Keuangan Yogyakarta.

Implikasi teoritis pada penelitian ini, yaitu organisasi pembelajar yang secara efektif mengelola siklus terintegrasi Knowledge Management menjadikan individu lebih inovatif dalam menumbuhkan semangat dan budaya untuk terus belajar dengan melakukan (learning by doing), mewujudkan ide-ide inovatif, serta memberikan kontribusi terbaiknya bagi organisasi pembelajar. Lebih lanjut, Knowledge Capture dan Knowledge Sharing and Dissemination pada hasil analisis belum membuktikan pengaruhnya terhadap Perilaku Kerja Inovatif SDM. Walaupun penelitian lain berasumsi bahwa Perilaku Kerja Inovatif SDM dapat diwujudkan melalui efektivitas praktik siklus terintegrasi Knowledge Management namun hal tersebut bukan menjadi faktor utama penentu keterlibatan dalam mempengaruhi Perilaku Kerja Inovatif SDM di organisasi pembelajar. Maka dari itu untuk penelitian selanjutnya agar memperhatikan indikator-indikator lain sebagai faktor penentu keberhasilan yang mempengaruhi Perilaku Kerja Inovatif SDM terkait Knowledge Capture dan Knowledge Sharing and Dissemination yang tidak terdapat dalam penelitian ini.

Implikasi praktis pada penelitian ini sebaiknya Knowledge Capture dan Knowledge Sharing and Dissemination dapat ditingkatkan kembali urgensinya menjadi lebih spesifik agar dapat memberi dukungan kepada seluruh elemen ASN di Balai Diklat Keuangan Yogyakarta sesuai Keputusan Kepala BPPK No. KEP-140/PP/2017 yang mengatur bahwa tugas Knowledge Management adalah seluruh pegawai Kementerian Keuangan. Sebaiknya peraturan tentang Knowledge Management di Kementerian Keuangan bentuknya Peraturan Menkeu agar dapat mengikat seluruh pegawai Kementerian Keuangan. Dengan semangat ASN Corporate University diharapkan dapat menumbuhkan kemauan dan pembentukan kebiasaan untuk terus belajar di berbagai kesempatan, hingga pada akhirnya ide-ide, inovasi dan pengetahuan baru dapat diwujudkan, disebarkan dan diakuisisi oleh institusi Sehingga, baik Balai Diklat Keuangan Yogyakarta maupun unit diklat lain dapat memberikan lebih dari diklat dan belajar tanpa batas sesuai dengan slogan BPPK.

\section{DAFTAR PUSTAKA}

Abukhait, R. M., Bani-Melhem, S., \& Zeffane, R. (2018). Empowerment, Knowledge Sharing and Innovative Behaviours: Exploring Gender Differences. International $\begin{array}{lllll}\text { Journal of Innovation } & \text { Management, } & \text { 23(1), }\end{array}$ https://doi.org/10.1142/S1363919619500063

Asegaff, \& Wasitowati. (2015). Knowledge Sharing Sebagai Sumber Inovasi dan Keunggulan Bersaing Pada Usaha Mikro Kecil dan Menengah (UMKM) Sektor Batik. CBAM Journal of Business, Accounting and Management, 2(1), 208-221.

BAPPENAS. (2019). Rancangan Teknokratik Rencana Pembangunan Jangka Menengah Nasional 2020 - 2024 : Indonesia Berpenghasilan Menengah - Tinggi Yang Sejahtera, Adil, dan Berkesinambungan. In Kementerian PPN/ Bappenas.

Dalkir, K. (2013). Knowledge Management In Theory And Practice (1st ed.). Oxford: Elsevier.

Darroch, J. (2005). Knowledge Management, Innovation and Firm Performance. Journal of Knowledge Management, 9(3), 101-115. https://doi.org/10.1108/13673270510602809

De Jong, J., \& Den Hartog, D. (2010). Measuring Innovative Work Behaviour. Creativity and Innovation Management, 19(1), 23-36. https://doi.org/10.1111/j.1467$\underline{8691.2010 .00547 . \mathrm{x}}$

Downes, T. V. (2014). An Evaluation of Knowledge Management Practices in Nonprofit Community Services Organisations in Australia (Southern Cross Business School). 
Edukasi Keuangan BPPK. (2017). Edukasi Keuangan Edisi 42/2017. Retrieved from https://bppk.kemenkeu.go.id/images/file/majalahedukasi/ek42.pdf

Edukasi Keuangan BPPK. (2018). Edukasi Keuangan Edisi 44/2018. Retrieved from https://bppk.kemenkeu.go.id/images/postingan/setban/2018/EDUKASI44.pdf

Etikariena, A. (2018). Perbedaan Perilaku Kerja Inovatif Berdasarkan Karakteristik Individu Karyawan. Jurnal Psikologi, 17(2), 107-118.

Hatmoko, A. W., \& Suharsono, A. (2018). Kemenkeu Corpu Governance Sebagai Patok Banding Jabar Corpu Governance. Prosiding Seminar Nasional "INOVASI MENUJU CORPORATE UNIVERSITY, ” 61-68. Jawa Barat: BPSDM Provinsi Jawa Barat.

Ikrahmawati. (2016). Pengaruh Knowledge Management Terhadap Kinerja Karyawan (Studi pada PT. Kumala Motor Sejahtera Abadi Kendari). Universitas Halu Uleo Kendari.

Janssen, O. (2000). Job demands, Perceptions of Effort-reward Fairness and Innovative Work Behavior. Journal of Occupational and Organizational Psychology, 73(3), 287 302. https://doi.org/https://doi.org/10.1348/096317900167038

KaBPPK. (2017). Keputusan Kepala BPPK No. KEP-140/PP/2017 tentang Cetak Biru Kemenkeu Corpu. Jakarta.

Khodakarami, P., \& Zakaria, Z. (2015). The Relationship between Innovative Behavior and Sustainable Development. European Journal of Business and Management, 7(23), 160-169. Retrieved from http://www.iiste.org/Journals/index.php/EJBM/article/view/25071

LaKin BPPK. (2017). Laporan Kinerja Badan Pendidikan dan Pelatihan Keuangan Tahun 2017. Jakarta.

Lee, J. (2018). The Effects of Knowledge Sharing on Individual Creativity in Higher Education Institutions: Socio-Technical View. Administrative Sciences, 8(2), 1-16. https://doi.org/10.3390/admsci8020021

Liao, S. H., \& Wu, C. C. (2009). Knowledge Management and Innovation: The Mediating Effects of Organizational Learning. IEEM 2009 - IEEE International Conference on Industrial Engineering and Engineering Management, 1850-1854. https://doi.org/10.1109/IEEM.2009.5373187

McInerney, C. R., \& Koenig, M. E. D. (2011). Knowledge Management (KM) Processes in Organizations: Theoretical Foundations and Practice. Synthesis Lectures on Information Concepts, Retrieval, and Services, 3(1), 1-96. https://doi.org/10.2200/s00323ed1v01y201012icr018

Mesmann, G. (2012). Innovative Work Behaviour: Investigating The Nature and Facilitation of Vocational Teachers' Contributions to Innovation Development. University of Regensburg.

Nonaka, I., Ayano, H. N., \& Hideki, K. (2018). Knowledge-Based Management Theory. In Knowledge Creation in Public Administrations: Innovative Government in Southeast Asia and Japan. Tokyo: Palgrave Macmillan.

Nurul, I., \& Dhiani, D. (2015). Manajemen Pengetahuan: Teori dan Praktik. Yogyakarta: Gadjah Mada University Press.

Pemerintah RI. (2010). Peraturan Presiden Nomor 81 Tahun 2010 tentang Grand Design Reformasi Birokrasi 2010-2025. In Peraturan Presiden Republik Indonesia. Retrieved from http://www.bpkp.go.id/uu/filedownload/5/4/1871.bpkp

PKP2A III LAN. (2018, April). BinnetMagz: Media Cerdas Untuk Aparatur Berintegritas (Edisi April 2018). 1-29.

Rahimi, E., Rostami, N. A., Shad, F. S., \& Vafaei, V. (2017). The Importance of Knowledge 
Management on Innovation. Management Research Review, 5(1), 68-72. Retrieved from

https://www.researchgate.net/publication/328791839_The_importance_of_knowledg e_management_on_innovation

Sangkala. (2007). Knowledge Management. Jakarta: PT Raja Grafindo Persada.

Sartika, D. (2018, April). Corporate University, Apa Itu? ProkalNews. Retrieved from https://news.prokal.co/read/news/2800-corporate-university-apa-itu.html

Schwartz, D. G. (2006). Encyclopedia of Knowledge Management. London: Idea Group Reference.

Subangun, R. (2018). Implementasi Knowledge Management Pada Kinerja Karyawan di Balai Diklat Keuangan Yogyakarta. E-Jurnal Prodi Teknologi Pendidikan, 7(8), 751762.

Suharsono, A. (2018). Implementasi Knowledge Management Dalam Kemenkeu Learning Center. (Seminar Nasional Perpajakan), 1-15.

Uriarte, F. A. (2008). Introduction To Knowledge Managemant. Jakarta: ASEAN Foundation.

Zhou, W., \& Velamuri, V. K. (2018). Key Contextual Success Factors for Employee Innovative Behavior: a Study in a Foreign Manufacturing Subsidiary in China. Cogent Business and Management, $5(1)$ $1-18$. https://doi.org/10.1080/23311975.2018.1471770 